\title{
Breeding sites of Neotropical Drosophilidae (Diptera). IV. Living and fallen flowers of Sessea brasiliensis and Cestrum spp. (Solanaceae)
}

\author{
Rita de Cassia Oliveira dos Santos ${ }^{1,2} \&$ Carlos Ribeiro Vilela ${ }^{3}$
}

\begin{abstract}
${ }^{1}$ Departamento de Zoologia, Instituto de Biociências, Universidade de São Paulo, Caixa Postal 11461, 05422-970 São Paulo-SP, Brazil ${ }^{2}$ Current address : Universidade Federal do Pará, Campus Universitário de Bragança, Alameda Leandro Ribeiro s/n, Aldeia, 68600-000 Bragança-PA, Brazil.rcos@ufpa.br

${ }^{3}$ Departamento de Genética e Biologia Evolutiva, Instituto de Biociências, Universidade de São Paulo, Caixa Postal 11461 05422-970, São Paulo-SP, Brazil. crvilela@ib.usp.br
\end{abstract}

\begin{abstract}
Breeding sites of Neotropical Drosophilidae (Diptera). IV. Living and fallen flowers of Sessea brasiliensis and Cestrum spp. (Solanaceae). The flowering phenologies of Sessea brasiliensis and three species of Cestrum (C. amictum, C. schlechtendalii and C. sendtnerianum), all belonging to the Solanaceae, were monitored in a fragment of the montane Atlantic rain forest within São Paulo city from July 1993 through June 1995. A total of 11,021 flies belonging to five species of the flavopilosa group of Drosophila (D. cestri, D. cordeiroi, D. hollisae, D. incompta and D. mariaehelenae), plus 1,244 flies belonging to four species of Zygothrica (Z. dispar, Z. vittimaculosa, Z. vittinubila and Z. aff. vittipunctata) emerged from 33,955 sampled flowers. Cestrum amictum, C. sendtnerianum and Sessea brasiliensis are recorded for the first time as host plants for the species of the Neotropical flavopilosa group of Drosophila. Additionally, at least ten less abundant taxa belonging also to the Drosophilidae, plus 1,073 microhymenopteran parasitoids (Braconidae, Eucoilidae, and Pteromalidae), emerged from the sampled flowers of S. brasiliensis e Cestrum spp. The present study raised from nine to eleven the number of species of Cestrum previously recorded as breeding sites for these flies. A comprehensive list of species of Solanaceae known to host six species of Drosophila and four species of Zygothrica in southeastern and southern Brazil is included.
\end{abstract}

KEYWORDS. Atlantic Forest; Brazil; Drosophila spp.; microhymenopteran parasitoids; Zygothrica spp.

RESUMO. Sítios de desenvolvimento larval de Drosofilídeos (Diptera) neotropicais. IV. Flores de Sessea brasiliensis e Cestrum spp. (Solanaceae) coletadas nas plantas e no solo. As fenologias de floração de quatro espécies de Solanaceae (Sessea brasiliensis, Cestrum amictum, C. schlechtendalii e C. sendtnerianum) presentes em um fragmento de Floresta Atlântica de planalto, encravado na cidade de São Paulo, foram determinadas por observações realizadas entre julho de 1993 e junho de 1995. Durante esses dois anos foram coletadas 33.955 flores das quais emergiram 11.021 moscas pertencentes a cinco espécies de Drosophila do grupo flavopilosa (D. cestri, D. cordeiroi, D. hollisae, D. incompta e D. mariaehelenae) e 1.244 moscas pertencentes a quatro espécies Zygothrica (Z. dispar, Z. vittimaculosa, Z. vittinubila e $Z$. aff. vittipunctata). Adicionalmente, das flores de $S$. brasiliensis e Cestrum spp. amostradas emergiram pelo menos outros dez táxons menos abundantes de Drosofilídeos e 1.073 microimenópteros parasitóides (Braconidae, Eucoilidae e Pteromalidae). Flores de Cestrum amictum, C. sendtnerianum e Sessea brasiliensis são registradas pela primeira vez como plantas hospedeiras para as espécies neotropicais de Drosophila pertencentes ao grupo flavopilosa. Os resultados aqui apresentados elevam de nove para onze o número de espécies de Cestrum previamente conhecidas como sítios de desenvolvimento larval dessas moscas. Inclui-se ainda uma lista completa das espécies de Solanaceae que já foram registradas nas regiões sudeste e sul do Brasil como plantas hospedeiras de seis espécies de Drosophila do grupo flavopilosa e de quatro espécies de Zygothrica.

PALAVRAS-CHAVE. Brasil; Drosophila spp.; Mata Atlântica; microimenópteros parasitóides; Zygothrica spp.

Many species of holometabolic insects use ephemeral resources (e.g. fungi, flowers, fruits, etc.) as sites for adult feeding and courting, and larval development. There is, however, variation in the degree of specificity in relation to their host plants. This variation might be related to diverse factors, such as predictability and availability of plant resources in time and space, the diversity of plant species within a community, and the spatial relationships and associations among individual plants (Cates 1980, 1981; Vasconcellos-Neto 1991).

Some species of insect that use ephemeral resources, however, have become highly specialized. Those using one or a few species of plants belonging to the same family are considered monophagous, whereas those breeding from a wide spectrum of families of host plants are named polyphagous (sensu Montgomery 1975).

The level of specialization among insects with regard to different species of plant must be related not only to intrinsic features of the plants, but also to behavioral, physiological and ecological features of the insects. Aspects such as the level of development of the nervous system, related to the sensorial organs of the insects, as well as abundance, and spatial and temporal distribution of the plant species, must be involved in the optimum use of a given plant (Jermy 1984, 1988; Vasconcellos-Neto 1991).

The flavopilosa group of Drosophila was proposed by Wheeler et al. (1962), who surmised that plant species of the genus Cestrum (Solanaceae) were the main breeding sites of 
the species of this group. However, the authors did not have enough ecological information on all the described species to test their hypothesis. The Solanaceae is a highly diversified family, with about 96 genera and 2,300 species (D'Arcy 1991). The Neotropical genus Cestrum L. encompasses about 175 species with wide geographic distribution in the Neotropics (D'Arcy 1991). Sixteen species of this genus (including both exotic and native species) and three varieties have been recorded in São Paulo State (Aranha, C., UNICAMP, Ph.D. unpublished thesis). The flowering periods of Cestrum species are varied, but may overlap in certain areas.

The Neotropical and mostly Andean genus Sessea Ruiz \& Pavón, belonging to the same tribe (Cestreae) of the genus Cestrum, includes ca. 18 species (Benítez 2001), out of which one (S. brasiliensis Toledo) is endemic to southeastern Brazil, and one ( $S$. regnelli Taubert) occurs only in southern and southeastern Brazil. Although there is a relatively recent proposal (Carvalho \& Schnoor 1993/1997) of reducing the genus Sessea to a section within the genus Cestrum at least for those two Brazilian species cited above, for which two new names (Cestrum toledii Carvalho \& Schnoor and Cestrum capsulare Carvalho \& Schnoor, respectively) have also been proposed (because of new homonymies), we opted to keep the species brasiliensis in the genus Sessea until more discussion on the subject is available in the literature.

Pipkin et al. (1966) studied different types of substrata used for breeding by drosophilids in Panama. After breeding seven undetermined species of Drosophila belonging to the flavopilosa group from flowers of eighteen plant species belonging to nine families, it was concluded that the flavopilosa group is polyphagous. More recently, however, Sepel et al. (2000) collected flowers of unspecified species belonging to some of the genera examined by Pipkin et al. (1966), namely Aphelandra, Brunfelsia, Calathea, Datura, Heliconia, Petunia, and Solanum, from which no flies of the flavopilosa group emerged.

Drosophila flavopilosa is the only species of its group that emerged from the flowers of Cestrum parqui in Chile (Brncic 1966). The remaining species of the group flavopilosa, however, usually congregate in multi-specific assemblies on the flowers of different species of Cestrum in other geographic areas. Eight species of Cestrum, namely C. calycinum Willd., C. corymbosum Schltdl, C. euanthes Schltdl., C. intermedium Sendtn., C. parqui L'Hér, C. parvifolium Willd. Ex Roem. \& Schult., C. schlechtendalii G. Don, and C. tomentosum L. f., have been recognized as host plants of seven out of twelve described species of the flavopilosa group (Brncic 1966, 1978; Vilela 1984; Hunter 1992; Vilela \& Pereira 1992; Sepel et al. 2000). They are as follows: $D$. acroria Wheeler \& Takada in Wheeler et al. 1962, D. cestri Brncic, 1978, D. cordeiroi Brncic, 1978, D. flavopilosa Frey, 1919, D. hollisae Vilela \& Pereira, 1992, D. incompta Wheeler \& Takada in Wheeler et al. 1962, and D. mariaehelenae Vilela, 1984).

The host plants for the remaining five species $(D$. crossoptera Wheeler \& Takada in Wheeler et al. 1962, D. gentica Wheeler \& Takada in Wheeler et al. 1962, D. lauta
Wheeler \& Takada in Wheeler et al. 1962, D. melina Wheeler, 1962, and D. nesiota Wheeler \& Takada in Wheeler et al. 1962) are as yet unknown.

It should be pointed out that imagines (species not stated) belonging to the Drosophila flavopilosa species group were also reported (Vilela \& Pereira 1992:478) emerging from flowers of the exotic and ornamental Cestrum nocturnum L. collected in São Paulo city.

Four additional and undescribed species of Drosophila belonging to this group have been recently reported by Vela \& Rafael (2003) in the Ecuadorian province of Pichincha, two of which were just described (Vela \& Rafael 2004). However, in our opinion, one of them (Drosophila ogradi Vela \& Rafael 2004) clearly belongs to a different group, which was recently proposed as the Drosophila morelia species group (Vilela \& Bächli 2004).

In Brazil, six species of Drosophila of the flavopilosa group, namely $D$. cestri, $D$. cordeiroi, D. flavopilosa, D. hollisae, $D$. incompta, and $D$. mariaehelenae, have been recorded using flowers of a list of five species of Cestrum (C. calycinum, $C$. corymbosum, $C$. intermedium, $C$. parqui and $C$. schlechtendalii) as breeding sites. Two of these species, namely $D$. hollisae and $D$. mariaehelenae, are apparently restricted to southeastern Brazil (State of São Paulo). $D$. flavopilosa has only been recorded in southernmost Brazil (State of Rio Grande do Sul), emerging together with other species of its group. D. cestri, D. cordeiroi and D. incompta have been registered in both regions emerging from different species of Cestrum (Brncic 1978; Napp \& Brncic 1978; Hofmann \& Napp 1984; Vilela 1984; Hofmann 1985; Vilela \& Pereira 1992; Sepel et al. 2000).

Some years ago, the flowering phenology of species belonging to the genera Cestrum and Sessea (Solanaceae) were monitored, in association with the collection of their flowers, at a fragment of a montane Atlantic rain forest in southern São Paulo city yielding new data on the ecology of the flavopilosa species group.

This paper is the fourth of a series (Vilela \& Pereira 1992; Vilela \& Selivon 2000; Vilela 2001) aiming to unveil the breeding sites of Neotropical drosophilids. It presents the results of the analysis of flies that emerged from the flowers of four monitored species of Solanaceae. Some ecological data on flies emerged from flowers of two additional species of Cestrum $(C$. corymbosum and C. nocturnum) collected in the municipality of Ibiúna and in São Paulo city (state of São Paulo) respectively were also included.

\section{MATERIALS AND METHODS}

The flower samples were collected at a Biological Reserve of the Instituto de Botânica, located in the city of São Paulo ( $23^{\circ} 39^{\prime}$ S, $46^{\circ} 37^{\prime}$ W), State of São Paulo, southeastern Brazil. It occupies an area of about 163 ha, characterized as montane Atlantic rain forest, and represents a fragment of the original forest within the high urbanized area of the city. This fragment is relatively old, being isolated for more than 50 years (Tabarelli 


\begin{tabular}{|l|l|c|c|c|c|c|c|c|c|c|c|c|c|c|c|c|c|c|c|c|c|c|c|}
\hline \multicolumn{10}{|c|}{1993} & \multicolumn{10}{|c|}{1994} & \multicolumn{1}{|c|}{1995} \\
\hline J & A & S & O & N & D & J & F & M & A & M & J & J & A & S & O & N & D & J & F & M & A & M & J \\
\hline
\end{tabular}

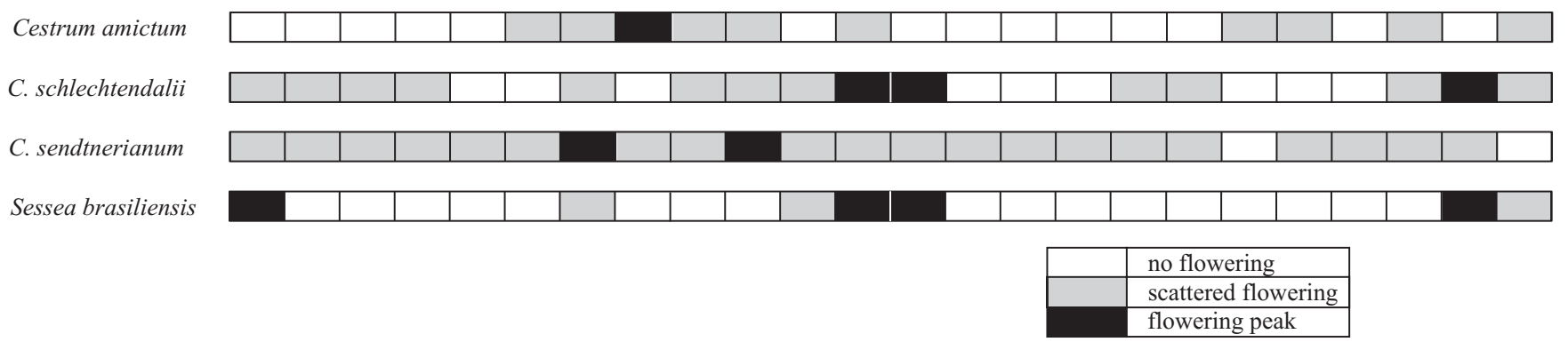

Fig. 1. Flowering phenology of four species of Solanaceae monitored at the Biological Reserve of the Instituto de Botânica, São Paulo city, SP, Brazil, from July 1993 through June 1995.

et al. 1999) and belongs to a larger fragment of 370 ha of a state park named Parque Estadual das Fontes do Ipiranga.

According to Carvalho (1985), 12 genera (e.g. Cestrum and Sessea) and 42 species of Solanaceae occur in the Biological Reserve. This study area was chosen because of its relative proximity to our lab allowing ecological analysis of both the flies and their several sympatric and potential host plants. During a two-year study, from July 1993 through June 1995, a total of 17 specimens belonging to three species of the genus Cestrum, namely C. amictum Schltdl. (2 specimens), $C$. schlechtendalii (7 specimens), C. sendtnerianum Mart. (8 specimens), in addition to 20 specimens of Sessea brasiliensis, were monitored in the area of the Reserve. The shrub-sized specimens of Cestrum ssp. and the tree-sized specimens of Sessea brasiliensis produced small, morphologically very similar, tubular flowers, and were mostly found along trails. The Cestrum species have berry like fruits, while the Sessea species produces dried dehiscent ones.

Plant vouchers of these four Solanaceae species were deposited at the herbarium of the Instituto de Botânica (coded SP), São Paulo, state of São Paulo, Brazil, and kindly identified by their staff, especially Dr. Lucia Rossi.

During the monitoring period, collections of living, mostly opened flowers (the complete flower was broken off the plant), and of those fallen on the ground (just the tubular corolla, as the calyx and pistil remain on the plant) were carried out for all species except $C$. sendtnerianum, from which only living flowers were collected. The samples size varied in accordance with the availability of flowers during the year. The samples were taken to the laboratory separately, according to plant species, in screen-capped plastic boxes and then deposited in $250 \mathrm{ml}$ vials (100 flowers per vial) containing moist sand and plugged with synthetic foam stoppers. The vials were kept in an incubator with constant temperature $\left(22 \pm 1^{\circ} \mathrm{C}\right)$ and photoperiod (13 h: $11 \mathrm{~h}, \mathrm{~L}: \mathrm{D})$ to await emergence of adult drosophilids and other insects. Whenever necessary, water was added by a plant sprayer to prevent desiccation.

All emerged insects were removed daily late in the afternoon by an aspirator until no further emergence took place (ca. 4 weeks later), and kept on a banana-agar culture media to await hardening and darkening of the exoskeleton (ca. 20 days). All emerged drosophilids were sexed and, whenever possible, identified to species level. Males of the Drosophila flavopilosa group were identified by the inspection of the distal extremity of aedeagi according to the technique of gently pressing the abdominal tip of anesthetized flies as proposed by Spassky (1957). Females were identified only to group due to the lack of reliable diagnostic characters. Thus, only males were used to calculate the abundance and relative frequency of the species belonging to flavopilosa group.

Additionally, flies that emerged from flowers of Cestrum corymbosum and $C$. nocturnum (cultivated as ornamental) collected in the state of São Paulo, at the municipality of Ibiúna and São Paulo city respectively, were aspirated and processed using the same method as described above.

Voucher specimens of each insect species were doublemounted to a point (or pinned) and were deposited in the Museu de Zoologia, Universidade de São Paulo, São Paulo (MZSP). Voucher specimens of host plants were deposited in the herbarium stated above.

\section{RESULTS ANDDISCUSSION}

Two out of the three identified species of Cestrum $(C$. amictum and $C$. sendtnerianum) sampled in the area of the Biological Reserve were recorded for the first time as breeding sites for four species of Drosophila of the flavopilosa group (Table IV), thus the number of species of Cestrum known to be used as breeding sites for these species rose from nine to eleven. This is the second record of larval development of species of the flavopilosa group in flowers of $C$. schlechtendalii at the city of São Paulo (previously recorded by Vilela \& Pereira 1992).

A total of 14,825 living flowers and 3,430 fallen flowers of the three species of Cestrum were collected in the area of the Biological Reserve (Table I). Two of the three species of Cestrum sampled, namely: C. amictum and C. schlechtendalii, differ from the other by possessing more regular flowering periods (Fig. 1). The former flowers more intense during mid summer (February), while the latter flowers mostly during the 
Table I. Total number of living and fallen flowers of four species of Solanaceae (genera Cestrum and Sessea) collected at the Biological Reserve of the Instituto de Botânica, São Paulo city, SP, Brazil, from July 1993 through June 1995.

\begin{tabular}{lccc}
\hline Species of Solanaceae & $\begin{array}{c}\text { Living } \\
\text { flowers }\end{array}$ & $\begin{array}{c}\text { Fallen } \\
\text { flowers }\end{array}$ & Total \\
\hline Cestrum amictum & 3,560 & 1,326 & 4,886 \\
Cestrum schlechtendalii & 5,944 & 2,104 & 8,048 \\
Cestrum sendtnerianum & 5,321 & - & 5,321 \\
Sessea brasiliensis & 9,800 & 5,900 & 15,700 \\
\hline Total & 24,625 & 9,330 & 33,955 \\
\hline
\end{tabular}

early winter (June) (Vilela \& Pereira 1992; Rossi 1994), however, there were overlaps mainly during their less intense flowering periods.

In the studied area, $C$. sendtnerianum differs from other two species of Cestrum by presenting an almost continuous flowering all year long (with some bursts), probably being the only available resource during some months of the year to some species of drosophilids (Fig.1). Only eight individuals of this most abundant Cestrum species at the Biological Reserve of the Instituto de Botânica were monitored along the study trails, although more specimens were also spotted. Vasconcellos-Neto (1991) stated that Cestrum sendtnerianum also occurs in high densities at the Horto Florestal de Sumaré, São Paulo state. While in the latter reserve it has been found in shady and humid areas, at the Biological Reserve of the Instituto de Botânica it was found mainly in disturbed areas, i. e. along the trails and on the borders of the reserve.

A total of 15,700 flowers of Sessea brasiliensis were sampled and this species was recorded for the first time as a host plant for species belonging to the flavopilosa group of Drosophila. This species flowers mainly during late fall (May) and early winter (June) (Fig. 1), and is able to host larvae of the flavopilosa group as reported recently in the literature (Silva \& Martins 2004) based on a personal communication provided by the first author of the present paper.

A total of 5,122 males pertaining to five species of the flavopilosa group of Drosophila (D. cestri, D. cordeiroi, D. hollisae, D. incompta and D. mariaehelenae) were identified emerging from the flowers of Cestrum spp. (Table II). Due to the large difference in sample sizes of both living and fallen flowers, the results on the abundance of the emerged flies (presented as separated columns in both Tables II and III) were combined for discussion purposes. D. incompta was by far the most abundant species $(95.22 \%)$ and emerged from flowers of all the plant species sampled. D. mariaehelenae presented a low percentage of emergence (1.82\%) and also emerged from all plant species, although $C$. sendtnerianum was the preferred resource host plant. D. mariaehelenae was described by Vilela (1984) based on imagines emerged from flowers of $C$. intermedium collected in the municipality of Santa Isabel (misspelled as Izabel), state of São Paulo, where it represented ca. $50 \%$ of the flies that emerged from this resource. D. cordeiroi $(2.28 \%)$ and $D$. hollisae $(0.29 \%)$ share the same species of Cestrum (C. schlechtendalii and C. sendtnerianum) as breeding sites, but only $D$. cordeiroi emerged of the flowers of $S$. brasiliensis. D. cestri emerged from C. sendtnerianum and from $S$. brasiliensis, and also presented a low relative frequency $(0.39 \%)$. D. cestri coexists with $D$. incompta in $C$. calycinum and $C$. corymbosum flowers in two areas of Rio Grande do Sul state (Table IV), however, the former species emerged in high frequencies in the colder and wetter months, whereas the latter was the most common species in hot and dry periods (Sepel et al. 2000).

According to the observations of Vilela \& Pereira (1992), D. incompta was also the predominant species emerging from flowers of $C$. schlechtendalii in another biological reserve within São Paulo city, but a different order of abundance was verified regarding the other four species of the flavopilosa group that emerged. In contrast with the results of these authors, there was no emergence of specimens of $D$. cestri from flowers of $C$. schlechtendalii in the area of the Biological Reserve of the Instituto de Botânica.

Just one specimen ( $0.08 \%)$ of Zygothrica dispar emerged from fallen flowers of $C$. amictum (Table III). This species was already identified (Frota-Pessoa 1952) emerging from fallen flowers of another Solanaceae, vernacularly named "manacá" (Brunfelsia grandiflora), and of two other plants belonging to different families, in the State of Rio de Janeiro. These data suggest that Zygothrica dispar seems to be an opportunistic, polyphagous and ground-feeding species that could oviposit in any decaying flower.

Z. vittimaculosa had been previously reported as emerging

Table II. Number of males of five species of Drosophila belonging to the flavopilosa group which emerged from flowers of four Solanaceae species (genera Cestrum and Sessea) collected from July 1993 through June 1995, at the Biological Reserve of the Instituto de Botânica, São Paulo city, SP, Brazil.

\begin{tabular}{|c|c|c|c|c|c|c|c|c|c|c|c|}
\hline \multirow{3}{*}{$\begin{array}{l}\text { Species of } \\
\text { Drosophila }\end{array}$} & \multicolumn{11}{|c|}{ Host Plants } \\
\hline & \multicolumn{2}{|c|}{ C. amictum } & \multicolumn{2}{|c|}{ C. schlechtendalii } & \multirow{2}{*}{$\begin{array}{l}\text { C. sendtnerianum } \\
\text { L }\end{array}$} & \multicolumn{2}{|c|}{ S. brasiliensis } & \multicolumn{2}{|c|}{ Total } & \multicolumn{2}{|c|}{$(\%)$} \\
\hline & $\mathrm{L}$ & $\mathrm{F}$ & $\mathrm{L}$ & $\mathrm{F}$ & & $\mathrm{L}$ & $\mathrm{F}$ & $\mathrm{L}$ & $\mathrm{F}$ & $\mathrm{L}$ & $\mathrm{F}$ \\
\hline D. cestri & 0 & 0 & 0 & 0 & 2 & 5 & 13 & 7 & 13 & 0.18 & 1.12 \\
\hline D. cordeiroi & 0 & 0 & 4 & 0 & 30 & 56 & 27 & 90 & 27 & 2.27 & 2.33 \\
\hline D. hollisae & 0 & 0 & 1 & 0 & 14 & 0 & 0 & 15 & 0 & 0.38 & 0 \\
\hline D. incompta & 930 & 230 & 435 & 263 & 513 & 1,884 & 622 & 3,762 & 1,115 & 94.85 & 96.45 \\
\hline D. mariaehelenae & 1 & 1 & 1 & 0 & 88 & 2 & 0 & 92 & 1 & 2.31 & 0.08 \\
\hline Total & 931 & 231 & 441 & 263 & 647 & 1,947 & 662 & 3,966 & 1,156 & 100 & 100 \\
\hline
\end{tabular}

$\mathrm{L}=$ living flowers; $\mathrm{F}=$ fallen flowers. 
Table III. Males and females of five species of the genus Zygothrica which emerged from flowers of four species of Solanaceae (genera Cestrum and Sessea), collected from July 1993 through June 1995, at the Biological Reserve of the Instituto de Botânica, São Paulo, SP, Brazil.

\begin{tabular}{|c|c|c|c|c|c|c|c|c|c|c|c|}
\hline \multirow{3}{*}{$\begin{array}{l}\text { Species of } \\
\text { Zygothrica }\end{array}$} & \multicolumn{11}{|c|}{ Host Plants } \\
\hline & \multicolumn{2}{|c|}{ C. amictum } & \multicolumn{2}{|c|}{ C. schlechtendalii } & \multirow{2}{*}{$\begin{array}{l}\text { C. sendtnerianum } \\
\mathrm{L}\end{array}$} & \multicolumn{2}{|c|}{ S. brasiliensis } & \multicolumn{2}{|c|}{ Total } & \multicolumn{2}{|c|}{$(\%)$} \\
\hline & $\mathrm{L}$ & $\mathrm{F}$ & L & $\mathrm{F}$ & & L & $\mathrm{F}$ & $\mathrm{L}$ & $\mathrm{F}$ & $\mathrm{L}$ & $\mathrm{F}$ \\
\hline Z. dispar (male) & 0 & 1 & 0 & 0 & 0 & 0 & 0 & 0 & 1 & & \\
\hline Z. dispar (female) & 0 & 0 & 0 & 0 & 0 & 0 & 0 & 0 & 0 & 0 & 6.25 \\
\hline Z. vittimaculosa (male) & 0 & 0 & 36 & 0 & 9 & 3 & 2 & 48 & 2 & & \\
\hline Z. vittimaculosa (female) & 2 & 0 & 70 & 0 & 9 & 4 & 1 & 85 & 1 & 10.83 & 18.75 \\
\hline Z. vittinubila (male) & 16 & 3 & 22 & 0 & 7 & 0 & 0 & 45 & 3 & & \\
\hline Z. vittinubila (female) & 26 & 9 & 35 & 0 & 18 & 0 & 0 & 79 & 9 & 10.10 & 75 \\
\hline Z. aff. vittipunctata (male) & 1 & 0 & 1 & 0 & 466 & 0 & 0 & 468 & 0 & & \\
\hline Z. aff. vittipunctata (female) & 0 & 0 & 11 & 0 & 492 & 0 & 0 & 503 & 0 & 79.07 & 0 \\
\hline Total & 45 & 13 & 175 & 0 & 1,001 & 7 & 3 & 1,228 & 16 & 100 & 100 \\
\hline
\end{tabular}

$\mathrm{L}=$ living flowers; $\mathrm{F}=$ fallen flowers.

from flowers of $C$. intermedium in the municipality of Santa Isabel, São Paulo state (Vilela 1984), and from flowers of $C$. calycinum, C. corymbosum and Brunfelsia sp. at both Porto Alegre city and Santa Maria city, in the Rio Grande do Sul state (Sepel et al. 2000). At the Biological Reserve of the Instituto de Botânica, São Paulo, it also emerged from flowers of the four species of Solanaceae analyzed and represented $10.93 \%$ of the species of the genus Zygothrica. Z. vittinubila emerged also in the same proportion $(10.93 \%)$ as $Z$. vittimaculosa and was registered in the three species of Cestrum observed at the study area (Table III).

Zygothrica aff. vittipunctata, the most abundant (78.05\%) among the species of its genus (Table III), is closely related to $Z$. vittipunctata from which it mostly differs by having hookshaped gonopods (square-shaped in Z. vittipunctata), paraphyses bearing three setulae dorsodistally positioned (dorsoproximally in Z. vittipunctata) aedeagus medially straight (medially bent in $Z$. vittipunctata). We intend to describe this new species in a forthcoming paper.

Zygothrica aff. vittipunctata, Z. vittinubila and Z. dispar were recorded for first time emerging from flowers of Cestrum spp. (Table III).

Table IV shows a summary of all the reported data, including the present results, on the Solanaceae host plants to the flavopilosa species group of Drosophila as well as those belonging to the genus Zygothrica.

Additionally, at least ten less abundant taxa belonging also to the Drosophilidae emerged from the sampled flowers. According to the Solanaceae species, they are as follows: Cestrum schlechtendalii (fallen flowers)(Drosophila atrata, 1 female, V.1995); Cestrum sendtnerianum (living flowers) (Drosophila albirostris, 1 male, I.1994; Drosophila fragilis, 1 male, I.1994; unidentified species of the bromeliae group, 1 male, IX.1993; unidentified species of the tripunctata group, 2 females, I.1994; Cladochaeta aff. paradoxa, 1 male, I.1994; Scaptomyza sp., 1 female, IX.1993); Sessea brasiliensis (fallen flowers) (Drosophila griseolineata, 3 males and 5 females, VII.1993; D. sticta, 4 males, VI.1994; unidentified species of the cardini group, 1 female, VII.1993; and unidentified species of the tripunctata group, 2 females, VII.1993).
Drosophila fragilis, a species belonging to the tripunctata group and previously known from Mexico to Panamá, is recorded for the first time from the state of São Paulo, Brazil. De Toni et al. (2001:76) reported one specimen (sex undetermined), collected at a banana-baited trap in April 2000 at Arvoredo Island (state of Santa Catarina), they identified as probably belonging to this species (mispelled as $D$. fradilis). However, its identity must be checked because of its similarity with Drosophila trifilum, a species often attracted to bananabaited traps.

Drosophila sticta, a species not assigned to any known group of Neotropical Drosophila and previously found from El Salvador to Colombia, was recently also recorded in southeastern Brazil (Medeiros \& Klaczko 2004) based on one male specimen collected in a banana-baited trap at Santa Maria da Serra (Barreiro Rico farm, state of São Paulo) and identified by one of us (CRV) as belonging to this taxon. Its precise identification was possible thanks to the analysis of the male holotype terminalia, which will be shortly redescribed by CRV, who has previously reared two males of D. sticta from living flowers of Cestrum intermedium collected twenty-one years ago (Vilela 1984) at Santa Isabel, state of São Paulo. In that report Vilela (1984) was unable to identify the two males which were cited as "unidentified species" of the tripunctata group. At first sight, D. sticta might be confused with a species of the tripunctata group, especially Drosophila bandeirantorum because of its similar pattern of abdominal dark bands; however, the former (body length ca. $2.4 \mathrm{~mm}$ ) is much smaller than the latter (body length ca. $3.6 \mathrm{~mm}$ ).

Moreover, 1,073 microhymenopteran parasitoids (Braconidae, Eucoilidae e Pteromalidae) and 516 flies belonging to 9 additional families of Diptera (Cecidomyidae, Chloropidae, Lauxaniidae, Mycetophilidae, Phoridae, Psychodidae, Sciaridae, Sphaeroceridae, and Tipulidae) emerged from flowers of the four Solanaceae species at the Biological Reserve.

Except for the report by Pipkin et al. (1966) who considered the flavopilosa group as polyphagous, all the published data seems to indicate that members of this group behave in fact as monophagous (sensu Montgomery 1975). However, it should be pointed out that some species in this group present, indeed, 
Table IV. Species of the flavopilosa group of Drosophila and of Zygothrica which use living and fallen flowers of species of the Solanaceae genera Cestrum and Sessea recorded from Southern and Southeastern Brazil.

\begin{tabular}{|c|c|c|c|c|}
\hline $\begin{array}{l}\text { Species of } \\
\text { Drosophilidae }\end{array}$ & $\begin{array}{l}\text { Living } \\
\text { flowers }\end{array}$ & $\begin{array}{l}\text { Site of collection } \\
\text { (reference) }\end{array}$ & $\begin{array}{c}\text { Fallen } \\
\text { flowers }\end{array}$ & $\begin{array}{c}\text { Site of collection } \\
\text { (reference) }\end{array}$ \\
\hline \multirow[t]{6}{*}{ Drosophila cestri } & Cestrum calycinum & II (Brncic 1978); IX (Sepel et al. 2000) & - & - \\
\hline & C. corymbosum & IX (Sepel et al. 2000) & - & - \\
\hline & C. intermedium & III (Vilela 1984) & - & - \\
\hline & C. parqui & II (Brncic 1978) & - & - \\
\hline & C. schlechtendalii & VI (Vilela \& Pereira 1992) & - & - \\
\hline & Sessea brasiliensis & IV (this paper) & Sessea brasiliensis & IV (this paper) \\
\hline \multirow[t]{8}{*}{ D. cordeiroi } & Cestrum calycinum & II (Brncic 1978) & - & - \\
\hline & C. corymbosum & $\mathrm{V}$ (this paper) & - & - \\
\hline & C. intermedium & III (Vilela 1984) & - & - \\
\hline & C. parqui & II (Brncic 1978) & - & - \\
\hline & C. schlechtendalii & IV (this paper); VI (Vilela \& Pereira 1992) & - & - \\
\hline & C. sendtnerianum & IV (this paper) & - & - \\
\hline & - & - & Cestrum nocturnum & VII (this paper) \\
\hline & Sessea brasiliensis & IV (this paper) & Sessea brasiliensis & IV (this paper) \\
\hline D. flavopilosa & Cestrum parqui & I (Brncic 1978) & - & - \\
\hline \multirow[t]{2}{*}{ D. hollisae } & Cestrum schlechtendalii & IV (this paper); VI (Vilela \& Pereira 1992) & - & - \\
\hline & C. sendtnerianum & IV (this paper) & - & - \\
\hline \multirow[t]{9}{*}{ D. incompta } & Cestrum amictum & IV (this paper) & Cestrum amictum & IV (this paper) \\
\hline & C. calycinum & II (Brncic 1978); IX (Sepel et al. 2000) & - & - \\
\hline & C. corymbosum & $\mathrm{V}$ (this paper); IX (Sepel et al. 2000) & - & - \\
\hline & C. intermedium & III (Vilela 1984) & - & - \\
\hline & C. parqui & I (Brncic 1978) & - & - \\
\hline & C. schlechtendalii & IV (this paper); VI (Vilela \& Pereira 1992) & C. schlechtendalii & IV (this paper) \\
\hline & C. sendtnerianum & IV (this paper) & - & \\
\hline & - & & Cestrum nocturnum & VII (this paper) \\
\hline & Sessea brasiliensis & IV (this paper) & Sessea brasiliensis & IV (this paper) \\
\hline \multirow[t]{5}{*}{ D. mariaehelenae } & Cestrum amictum & IV (this paper) & Cestrum amictum & IV (this paper) \\
\hline & C. intermedium & III (Vilela, 1984) & - & - \\
\hline & C. schlechtendalii & IV (this paper); VI (Vilela \& Pereira 1992) & - & - \\
\hline & C. sendtnerianum & IV (this paper) & - & - \\
\hline & - & - & Cestrum nocturnum & VII (this paper) \\
\hline \multirow[t]{2}{*}{ Zygothrica dispar } & - & - & Brunfelsia grandiflora & VIII (Malogolowkin 1952) \\
\hline & - & - & Cestrum amictum & IV (this paper) \\
\hline \multirow[t]{7}{*}{ Z. vittimaculosa } & Cestrum amictum & IV (this paper) & Brunfelsia sp. & IX (Sepel et al. 2000) \\
\hline & C. calycinum & IX (Sepel et al. 2000) & Sessea brasiliensis & IV (this paper) \\
\hline & C. corymbosum & V (this paper); IX (Sepel et al. 2000) & - & - \\
\hline & C. intermedium & III (Vilela 1984) & - & - \\
\hline & C. schlechtendalii & IV (this paper); VI (Vilela \& Pereira 1992) & - & - \\
\hline & C. sendtnerianum & IV (this paper) & - & - \\
\hline & Sessea brasiliensis & IV (this paper) & - & - \\
\hline \multirow[t]{3}{*}{ Z. vittinubila } & Cestrum amictum & IV (this paper) & - & - \\
\hline & C. schlechtendalii & IV (this paper) & - & - \\
\hline & C. sendtnerianum & IV (this paper) & - & - \\
\hline \multirow{3}{*}{$\begin{array}{l}\text { Zygothrica aff. } \\
\text { vittipunctata }\end{array}$} & Cestrum amictum & IV (this paper) & - & - \\
\hline & C. schlechtendalii & IV (this paper) & - & - \\
\hline & C. sendtnerianum & IV (this paper) & - & - \\
\hline
\end{tabular}

Collections sites, followed by state abbreviation: I. Porto Alegre (Morro da Polícia), RS; II. Porto Alegre (Morro da Polícia), Eldorado do Sul [only D. incompta emerged; cited as El Dorado], Sapucaia do Sul [cited as Sapucaia] and Montenegro, RS; III. $11 \mathrm{~km}$ NE of Santa Isabel, SP; IV. São Paulo (Biological Reserve of the Instituto de Botânica de São Paulo), SP; V. Municipality of Ibiúna (country house named Recanto Aruanda), SP; VI. São Paulo (Forest Reserve of the Cidade Universitária "Armando de Salles Oliveira", São Paulo city, SP; VII. neighborhood of the Instituto de Biociências da Universidade de São Paulo, other than the Forest Reserve, São Paulo city, SP; VIII. Rio de Janeiro city (Botanic Garden), RJ; IX. Porto Alegre (Botanic Garden) and Santa Maria (Silvicultural Experimental Station), RS. 
greater plasticity with regard to the use of flower resources, such as the case of D. incompta, which is the most widespread among the flavopilosa group species, and has been reported as breeding in flowers of eight species of Cestrum (Table IV). Moreover, this species does not depend exclusively on Cestrum flowers to complete its larval development, at least under laboratory conditions, as reported by Ludwig et al. (2002) who bred four individuals in banana-agar culture media supplemented with baking powder.

The main factors that cause the species of the flavopilosa group to be associated with flowers, mostly of the Solanaceae species, must be related to nutritional and phytochemical features of the host plants. However, further studies are needed to test this hypothesis. On the other hand, pollination should be excluded as the adult flies are larger than the diameter of the tiny tubular flowers and therefore unable to enter the corollas.

It is likely that the original faunal composition and geographical distribution of the species of flavopilosa group of Drosophila in Brazil differed from the current condition, as a result of the fragmentation of the habitats and due to the introduction of some exotic species of both flies and their host plants (e.g., C. nocturnum) since the onset of European colonization. It should be pointed out that the Solanaceae are regarded as being composed of many ruderal species. Tabarelli et al. (1999) compared the species composition of woody plants within five montane Atlantic forest remnants (including the main area surveyed in the present report). They reported that as fragment size decreased, there is a marked rise in the relative importance of ruderal species, as seems to be the case with three Solanaceae species monitored here, namely Cestrum schlechtendalii, Cestrum sendtnerianum and Sessea brasiliensis. As the previous condition is unknown, it is difficult, if not impossible, to assess the impact of the introduction of these plants on the dynamics and the structure of populations of the flavopilosa species group of Drosophila.

Acknowledgements. We are indebted to the Administration of the Instituto de Botânica, São Paulo, for allowing collections of flowers and flies on its Biological Reserve, to Mr. Francisco Flauzino and to Drs. Lyria Mori, Maria Augusta Q.R. Pereira and Blanche C. P. BitnerMathé, Departamento de Genética e Biologia Evolutiva, Instituto de Biociências, Universidade de São Paulo, São Paulo, for help during many stages of this work, to several investigators of the Instituto de Botânica, especially Dr. Lucia Rossi, for identifying the host plants, to Dr. Marlúcia B. Martins, Museu Paraense "Emílio Goeldi", Belém, and to Dr. Beatriz Goñi, Universidad de la Republica, Montevidéu, for critically reading an early version of the manuscript, to Dr. Colin R. Beasley, Universidade Federal do Pará at Bragança and to Rachel Silva for revising the English version, to an anonymous referee for corrections and suggestions, to CAPES for granting a fellowship to RCOS during her master dissertation program, and to FINEP for some financial support (Proc. No. 66.93.018.00). RCOS is also grateful to a number of unnamed friends for helping her on several occasions.

\section{REFERENCES}

Benítez, C. 2001. Una nueva especie de Sessea (Solanaceae) de Loja, Ecuador. Novon 11: 298-301.
Brncic, D. 1966. Ecological and cytogenetical studies of Drosophila flavopilosa, a neotropical species living in Cestrum flowers. Evolution 20: 16-29.

Brncic, D. 1978. A note on the flavopilosa group of species of Drosophila in Rio Grande do Sul, Brazil, with the description of two new species (Diptera, Drosophilidae). Revista Brasileira de Biologia 38: $647-651$.

Carvalho, L. d'A. F. de. 1985. Flora Fanerogâmica da reserva do Parque Estadual das Fontes do Ipiranga (São Paulo, Brasil). Hoehnea 12: 67-85.

Carvalho, L. d'A. F. de \& A. Schnoor. 1993/97. Sessea Carvalho et Schnoor - nova seção para o gênero Cestrum (Solanaceae). Rodriguésia 45/49: 15-24.

Cates, R. G. 1980. Feeding patterns of monophagous, oligophagous and polyphagous insect herbivores: the effect of resource abundance and plant chemistry. Oecologia 46: 22-31.

Cates, R. G. 1981. Host plant predictability and the feeding patterns of monophagous, oligophagous and polyphagous insect herbivores. Oecologia 48: 319-326.

D'Arcy, W. G. 1991. The Solanaceae since 1976, with a Review of its Biogeography, p. 75-137. In: J. G. Hawkes; R. N. Lester; M. Nee \& N. Estrada-R (eds.) Solanaceae III. Taxonomy, Chemistry, Evolution. London, Royal Botanic Gardens/ Linnean Society of London, ix $+483 \mathrm{p}$.

De Toni, D. C.; P. R. P. Hofmann \& V. L. S. Valente. 2001. First record of Zaprionus indianus (Diptera, Drosophilidae) in the State of Santa Catarina, Brazil. Biotemas 14: 71-85.

Frota-Pessoa, O. 1952. Flower feeding Drosophilidae. Drosophila Information Service 26: 101-102.

Hofmann, P. R. P. 1985. Variabilidade genética em espécies de nicho ecológico restrito. Ciência e Cultura 37: 579-581.

Hofmann, P. R. P. \& M. Napp. 1984. Genetics-environmental relationships in Drosophila incompta, a species of restricted ecology. Revista Brasileira de Genética 7: 21-39.

Hunter, A. S. 1992. Flower-breeding Drosophila of Bogota, Colombia: New species (Diptera: Drosophilidae). Pan-Pacific Entomologist 68: 192-199.

Jermy, T. 1984. Evolution of insect/host plant relationships. The American Naturalist 124: 609-630.

Jermy, T. 1988. Can predation lead to narrow food specialization in phytophagous insects? Ecology 69: 902-904.

Ludwig, A.; N. M. Vidal; E. L. S. Loreto \& L. M. N. Sepel. 2002. Drosophila incompta development without flowers. Drosophila Information Service 85: 40-41.

Malogolowkin, C. 1952. Notas sôbre "Zygothrica dispar" (Diptera, Drosophilidae). Revista Brasileira de Biologia 12: 455-457.

Medeiros, H. F. de \& L. B. Klaczko. 2004. How many species of Drosophila (Diptera, Drosophilidae) remain to be described in the forests of São Paulo, Brazil? Biota Neotropica 4: 1-12.

Montgomery, S. L. 1975. Comparative breeding site ecology and the adaptive radiation of picture-winged Drosophila (Diptera: Drosophilidae) in Hawaii. Proceedings of the Hawaiian Entomological Society 22: 65-103.

Napp, M. \& D. Brncic. 1978. Electrophoretic variability in two closely related Brazilian species of the flavopilosa species group of Drosophila. Brazilian Journal of Genetics I: 1-10.

Pipkin, S. B.; R. L. Rodriguez \& J. Leon. 1966. Plant host specificity among flower-feeding neotropical Drosophila (Diptera, Drosophilidae). American Naturalist 100: 136-156.

Rossi, L. 1994. A Flora Arbóreo-Arbustiva da mata da Reserva da Cidade Universitária "Armando de Salles Oliveira" (São Paulo, Brasil). Boletim do Instituto de Botânica 9: 1-105.

Sepel, L. M. N.; R. M. Golombieski; M. Napp \& E. L. S. Loreto. 2000. Seasonal fluctuations of $D$. cestri and $D$. incompta, two species of the flavopilosa group. Drosophila Information Service 83: 122 126.

Silva, A. de A. R. da \& M. B. Martins. 2004. A new anthophilic species of Drosophila Fallén belonging to the bromeliae group of species (Diptera, Drosophilidae). Revista Brasileira de Zoologia 21: $435-437$. 
Spassky, B. 1957. Morphological differences between sibling species of Drosophila. The University of Texas Publications 5721: 4861.

Tabarelli, M.; W. Mantovani \& C. A. Peres. 1999. Effects of habitat fragmentation on plant guild structure in the montane Atlantic forest of southeastern Brazil. Biological Conservation 91: 199127.

Vasconcellos-Neto, J. 1991. Interactions between Ithomiine butterflies and Solanaceae: Feeding and reproductive strategies, p. 291-131. In: P. W. Price; T. M. Lewinsohn; G. W. Fernandes \& W. W. Benson (eds.) Plant-Animal interactions: Evolutionary Ecology in Tropical and Temperate Regions. New York, John Wiley, xiv+639p.

Vela, D. \& V. Rafael. 2003. Estudios sobre la diversidad del género Drosophila (Diptera, Drosophilidae) en el Bosque Pasochoa de la Provincia de Pichincha - Ecuador. Revista de la Pontificia Universidad Católica del Ecuador 71: 117-127.

Vela, D. \& V. Rafael. 2004. Dos nuevas especies del grupo flavopilosa, género Drosophila (Diptera, Drosophilidae) en el Bosque Pasochoa. Revista Ecuatoriana de Medicina y Ciencias Biológicas 26: $33-39$.
Vilela, C. R. 1984. Occurrence of the Drosophila flavopilosa species group (Diptera, Drosophilidae) in the state of São Paulo (Brazil) with description of one new species. Revista Brasileira de Zoologia 2: 63-69.

Vilela, C. R. 2001. Breeding sites of Neotropical Drosophilidae (Diptera). III. Rotting infructescences of Philodendron bipinnatifidum (Araceae). Revista Brasileira de Entomologia 46: 339-344.

Vilela, C. R. \& G. Bächli. 2004. Revisions of the Drosophila macroptera and D. rubrifrons species groups, with description of a new Neotropical group (Diptera, Drosophilidae). Mitteilungen der Schweizerischen Entomologischen Gesellschaft 77: 1-68.

Vilela, C. R. \& M. A. Q. R. Pereira. 1992. Breeding sites of Neotropical Drosophilidae (Diptera). I. Living flowers of Cestrum schlechtendalii (Solanaceae). Revista Brasileira de Entomologia 36: 475-482.

Vilela, C. R. \& D. Selivon. 2000. Breeding sites of Neotropical Drosophilidae (Diptera). II. Fallen fruits of Citharexylum myrianthum Cham. (Verbenaceae). Drosophila Information Service 83: 475-482.

Wheeler, M. R.; H. Takada \& D. Brncic. 1962. The flavopilosa species group of Drosophila. The University of Texas Publications 6205: 395-413. 